\title{
Effect of multidrug resistance modulators on the activity of ivermectin and moxidectin against selected strains of Haemonchus contortus infective larvae ${ }^{1}$
}

\author{
Marcelo B. Molento ${ }^{2}$ and Roger K. Prichard ${ }^{3}$
}

\begin{abstract}
Molento M.B. \& Prichard R. K. 2001. Effect of multidrug resistance modulators on the activity of ivermectin and moxidectin against selected strains of Haemonchus contortus infective larvae. Pesquisa Veterinária Brasileira, 21(3):117-121. Setor de Parasitologia, Universidade Paranaense, Umuarama, PR 87502-210, Brazil. E-mail: molento@unipar.br

Nematode parasites have shown resistance to the anthelmintics, ivermectin and moxidectin, and there is evidence that the over-expression of parasite P-glycoprotein (P-gp) may account, at least in part, for resistance to ivermectin. The objective of this study was to evaluate whether the multidrug resistance (MDR) modulators, verapamil, CL 347.099 (an analog of verapamil) and cyclosporin A, would enhance the efficacy of ivermectin and moxidectin against selected strains of Haemonchus contortus using an in vitro larval migration assay. The modulators had no effects on the number of migrating larvae when used alone. Ivermectin and moxidectin showed a significant $(\mathrm{P}<0.05)$ increase in its efficacy by 52.8 and $58.5 \%$ respectively, when used in association with verapamil against a moxidectin-selected strain. CL 347,099 also increased significantly $(\mathrm{P}<0.05)$ the ivermectin and moxidectin efficacy by 24.2 and $40.0 \%$ respectively, against an ivermectin-selected strain and by 40.0 and $75.6 \%$ respectively, against an moxidectinselected strain. At the concentrations tested cyclosporin A showed a variable effect on increasing the efficacy of the anthelmintics against the susceptible and resistant strains.
\end{abstract}

INDEX TERMS: Nematode, multidrug resistance (MDR), ivermectin, moxidectin, modulators, verapamil, CL 347.099, cyclosporin A.

RESUMO.- [Efeito de drogas moduladoras da resistência múltipla na atividade da ivermectina e moxidectina contra larvas infectantes selecionadas de Haemonchus contortus.] Existem relatos demonstrando a resistência de nematóides aos anti-helmínticos, ivermectina e moxidectina. $\mathrm{O}$ aumento da expressão da glicoproteína-P (P-gp) no parasita pode contribuir para o desenvolvimento da resistência a ivermectina. $\mathrm{O}$ objetivo deste trabalho foi avaliar se o uso combinado dos moduladores de resistência múltipla, verapamil, CL 347.099 (um análogo do verapamil) e ciclosporina $\mathrm{A}$ associados a ivermectina ou moxidectina, aumenta a eficácia dos anti-helmínticos contra cepas selecionadas de Haemonchus contortus, utilizando um experimento

\footnotetext{
${ }^{1}$ Accepted for publication on July 20, 2001.

${ }^{2}$ Setor de Parasitologia Veterinária, Universidade Paranaense, (UNIPAR), Praça Mascarenhas de Morais, s/n, Umuarama, PR 87502-210. E-mail: molento@unipar.br

${ }^{3}$ Institute of Parasitology, McGill University, 21111 Lakeshore Rd, Sainte Anne-de-Bellevue, Quebec, Canada H9X 3V9. E-mail: rprichard@parasit.lan.mcgill.ca
}

in vitro de migração de larvas. Ivermectina e moxidectina apresentaram um aumento significativo $(\mathrm{P}<0,05)$ de sua eficácia em 52,8 e $58,5 \%$, respectivamente, quando utilizadas em associação com o verapamil contra a cepa selecionada para moxidectina. CL 347.099 também aumentou significativamente $(\mathrm{P}<0,05)$ a eficácia de ivermectina e de moxidectina em 24,2 e $40,0 \%$, respectivamente, contra a cepa selecionada para a ivermectina e em 40,0 e $75,6 \%$ respectivamente, contra a cepa selecionada para moxidectina. Nas concentrações testadas, ciclosporina A apresentou resultados variáveis quando combinada com os anti-helmínticos. Quando utilizados sozinhos, os moduladores não apresentarão efeito na redução do número de larvas.

TERMOS DE INDEXAÇÃO: Nematóides, resistência múltipla (MDR), ivermectina, moxidectina, moduladores, verapamil, CL 347.099, ciclosporina A.

\section{INTRODUCTION}

To control the negative effects of parasite infection in farm animal producers worldwide rely heavily on the use of anthelmintic drugs. Many strains of nematodes have evolved 
resistance to one or more of the different classes of anthelmintics. Finding means to overcome anthelmintic resistance and maintain effective parasite control is becoming increasingly important. Ivermectin and moxidectin have a broad spectrum of activity against nematode parasites in livestock and humans. Resistance of Haemonchus contortus to ivermectin was first reported in sheep (Carmichael et al. 1987), and resistance to moxidectin was reported in Ostertagia spp in goats (Leathwick 1995). Multiple anthelmintic resistance (MAR) involving ivermectin and several other anthelmintics has also been reported (Waruiru 1997).

Multidrug resistance (MDR) is a phenomenon associated with the over expression of the membrane transport protein P-glycoprotein (P-gp) in MDR cells (Shustik et al. 1995, Wadkins \& Roepe 1997). P-gp functions as an ATP-driven, active efflux pump for many unrelated cytotoxic drugs, reducing the intracellular drug concentration. In the soil nematode Caenorhabditis elegans, P-gp has been shown to be responsible for protection against some toxins (Broeks et al. 1995). Pouliot et al. (1997), have proposed that ivermectin interacts with the P-gp drug-binding site in cancer cells, and ivermectin may be both a substrate and an inhibitor of P-gp (Didier \& Loor 1996). Recent findings showed that ivermectin-selected strains of $H$. contortus have higher levels of P-gp mRNA than do unselected strains (Xu et al. 1998), leading us to suggest that the over expression of P-gp in this parasite may be a consequence of ivermectin selection. Furthermore, Blackhall et al. (1998), found that repeated ivermectin and moxidectin treatment selected for a specific allele of P-gp in H. contortus. Sangster et al. (1999) have independently found selection on P-gp genes in ivermectin resistant field strains of $H$. contortus.

P-gp antagonists, termed MDR modulators have been used to augment drug activity against MDR organisms. These drugs are purported to compete with structurally unrelated drugs at the P-gp-binding site (Watanabe et al. 1995). The calcium channel blocker, verapamil, significantly increased the worm reduction effect of ivermectin and moxidectin against a moxidectin-selected strain of $H$. contortus in jirds (Xu et al. 1998). CL 347,099 has been proposed as an MDR modulator, having 70 fold less calcium channel blocker activity than verapamil (Greenberger et al. 1996). Cyclosporin A is an immunosuppressor that has been demonstrated to have MDR modulating properties when administered with cytotoxic agents in vitro and in vivo (Lum et al. 1993, Watanabe et al. 1995).

A series of experiments were designed to determine differences in the effect of ivermectin or moxidectin in the presence and in the absence of MDR candidates against larvae of unselected, ivermectin-, and moxidectin-selected strains of $H$. contortus. In order to assess the effects of these MDR candidates against the nematodes, without possible modulation of the effects on drug concentration by a host animal, and for reasons of economy and feasibility, a modified in vitro screening assay using third stage larvae of $H$. contortus was employed (D'Assonville et al. 1996).

\section{MATERIALS AND METHODS}

\section{Strains}

Three strains were selected after 17 passages in sheep. The selection of the isolates consisted of an experimental infection with infective third stage larvae from treatment survivors of the previous generations of $H$. contortus in naïve 4-6 month lambs with subsequent treatment with moxidectin or ivermectin in the case of the resistant strains or with no treatment in the case of the parental strain. The strains of $H$. contortus were denominated moxidectin-selected (MOF17), ivermectin-selected (IVF17) and unselected (PF17). A preliminary drug concentration curve was necessary to establish the approximate concentration that reduced larval counts by $50 \%$ (LD50) for the anthelmintics. The IVF17 and the MOF17 strains were shown to be 2 to 4 and 6 to 8 -fold more resistant to ivermectin and moxidectin, respectively compared to the PF17 strain in the larval migration assay. From this preliminary data, concentrations of 1 and $4 \mu \mathrm{M}$ for ivermectin and 8 and $16 \mu \mathrm{M}$ for moxidectin were estimated as the approximate LD50 against the unselected and selected strains, respectively. All strains were tested at the $12^{\text {th }}$ generation (PF12, IVF12, MOF12) in sheep to determine the differences in anthelmintic parasite elimination.

\section{Drugs}

Ivermectin (CDMV Inc., St. Hyacinth, Quebec) was used at 0.8 $\mathrm{mg} / \mathrm{ml}$ solution for sheep and moxidectin (Fort Dodge Animal Health, Princeton, NJ) was used at $0.01 \%$ drench solution in all experimental animals. Verapamil (Sigma, St. Louis, Missouri) and CL 347.099 (Fort

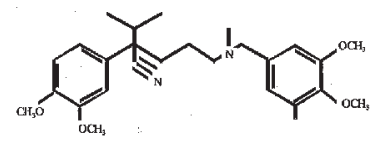

Verapamil

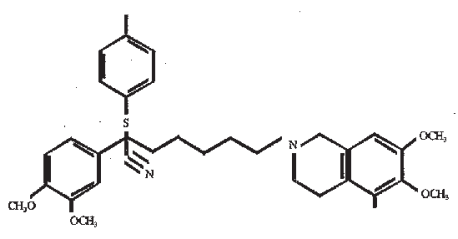

CL 347.099

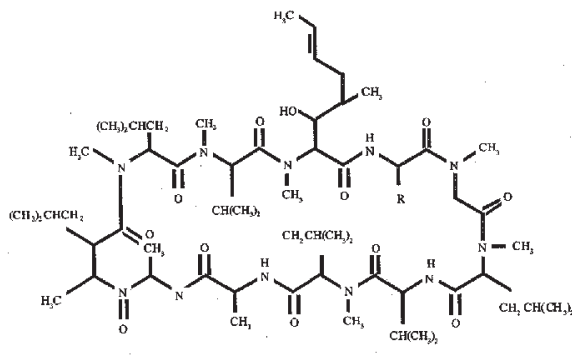

Cyclosporin A

Fig. 1. Chemical structure of the multidrug resistance reversing agents. 
Dodge Animal Health, Princeton, NJ) (Fig. 1) were diluted at $20 \mathrm{mM}$ with dimethyl sulfoxide (DMSO). Cyclosporin A (provided by Dr. E. Georges) (Fig. 1) was diluted at $10 \mathrm{mM}$ in ethanol. The standard solutions were further diluted with distilled water to the desired concentration before use.

The MDR reversing agents, Verapamil, CL 347,099 and cyclosporin A were tested alone in concentrations up to $100,100 \mathrm{mM}$, and $24 \mu \mathrm{M}$ respectively prior to the combination trials against all strains. The objective was to determine whether the MDR modulators alone had any effect on the migration of parasites and to select a dose that possessed no intrinsic effect, on its own, against the parasite. The diluents for all compounds were also tested.

\section{In vitro migration assay}

An assay modified from D'Assonville et al. (1996) was used. Infective third stage $\left(\mathrm{L}_{3}\right)$ larvae of $H$. contortus were collected from donor sheep feces and exsheathed using $0.073 \%$ of sodium hypochlorite for approximately two hours. When more then $90 \%$ of the motile larvae were exsheathed, they were washed three times in distilled water and subdivided in groups of 600. Larvae were placed in $0.5 \mathrm{ml}$ of distilled water while drug treatments $(0.5 \mathrm{ml})$ were prepared in separate vials. Drug solutions were then added to the water containing the $\mathrm{L}_{3}$ larvae and the vials placed in an incubator at $27^{\circ} \mathrm{C}$ for six hours. After that, $1 \mathrm{ml}$ of an agar solution (1.4\%) at $45^{\circ} \mathrm{C}$ was added to the treated larvae. The agar/larvae solution was then immediately transferred to a previously prepared apparatus using a $5 \mathrm{ml}$ pipette. The apparatus consisted of a Petri dish containing a plastic mesh on the base, a metal mesh and a plastic cylinder on the top. The apparatus was previously filled with $22 \mathrm{ml}$ of distilled water and put into a freezer allowing the frozen water to cover the mesh, leaving sufficient space on the plastic cylinder to fit the final solution. The apparatus was placed in an incubator for 18 hours at $27^{\circ} \mathrm{C}$ under a $150 \mathrm{MHz}$ light bulb after the solution was added. The exposure to light stimulates the larvae and allows the motile ones to migrate out of the agar portion. Following that, the liquid portion was poured into a $50-\mathrm{ml}$ centrifuge tube and allowed to settle, the final volume analyzed was $10 \mathrm{ml}$ disposing of the extra liquid. The tubes were then vortexed briefly and triplicate samples of $1 \mathrm{ml}$ were taken, $10 \mu \mathrm{l}$ of lugol iodine was added to the samples. Larval counts were estimated under a magnifying microscope and were multiplied by 10 . Experiments were performed in triplicates.

\section{Statistical analysis}

Anthelmintic effect was determined according the formula:

$$
\mathrm{E}=[(\mathrm{Mc}-\mathrm{Mtr}) / \mathrm{Mc}] \mathrm{x} 100
$$

Where, $\mathrm{E}$ is the percentage of efficacy, Mc is the mean number of larvae counted in the control group, and Mtr is the mean number of larvae counted in the treated group. Error bars account for the standard error for the mean (SEM). The percent increase was calculated by determining the initial percentage of efficacy of the anthelmintic alone group and compared them with the drug combination group. Comparison was made for each anthelmintic against its combination with the MDR modulators for each strain. Arithmetic means were used from triplicate experiments, and comparison between treatments was analyzed by Student's " $t$ " test.

\section{RESULTS}

CL 347.099 had no effect at concentrations up to $100 \mathrm{mM}$ when given alone against PF17 and IVF17 strains of $H$. contortus (Fig. 2). Propylene glycol, ethanol and dimethyl sulfoxide
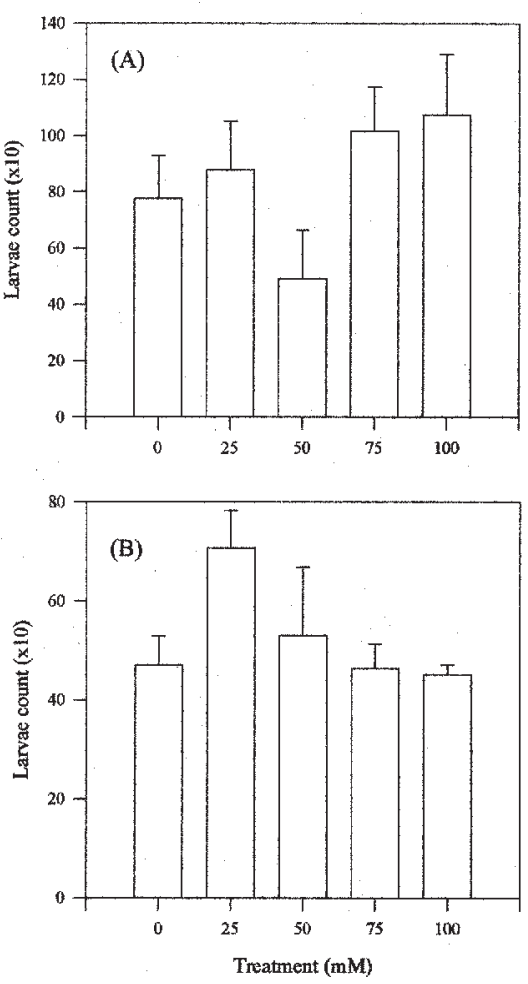

Fig. 2. Efficacy (SEM) of CL 347,099 alone against unselected (A) and ivermectin-selected (B) atrains of Haemonchus contortus.

showed no activity in reducing the number of migrating larvae when tested against the parasite isolates at 5, 10, and 50 and $100 \mathrm{mM}$ (data not shown).

Moxidectin in combination with verapamil $(2 \mathrm{mM})$ had an efficacy of $65 \%$ compared to $41 \%$ for moxidectin alone $(P=0.018)$ against the MOF17 strain, leading to an increase in efficacy of $58.3 \%$ (Table 1). Ivermectin in combination with verapamil also showed a significantly higher $(\mathrm{P}=0.048)$ effect $(84 \%)$ when compared with ivermectin alone (55\%) against the same strain (Fig. 3), leading to an increase in its efficacy of $52.7 \%$. When the combination was used against the IVF17 strain, verapamil significantly increased the efficacy of moxidectin but not of ivermectin from 59 (moxidectin alone) and 62\% (ivermectin alone) to $74(\mathrm{P}=0.019)$ and $74 \%$, respectively. Against the IVF17

Table 1. Percent increase of ivermectin or moxidectin efficacy with multidrug resistance modulators against selected Haemonchus contortus strains

\begin{tabular}{lcc}
\hline \multirow{2}{*}{ Treatment } & \multicolumn{2}{c}{ Percent efficacy } \\
\cline { 2 - 3 } & IVF17 & MOF17 \\
\hline IVM + VRP & 19.3 & $52.7^{*}$ \\
MOX + VRP & $25.4^{*}$ & $58.3^{*}$ \\
IVM + CL347,099 & $24.2^{*}$ & 40.0 \\
MOX + CL347,099 & $38.9^{*}$ & $75.6^{*}$ \\
IVM + CyA & $37.7^{*}$ & 0.0 \\
MOX + CyA & 36.4 & 15.7 \\
\hline
\end{tabular}

* Groups are significantly different from ivermectin/moxidectin treated groups $(\mathrm{P}<0,05)$. 

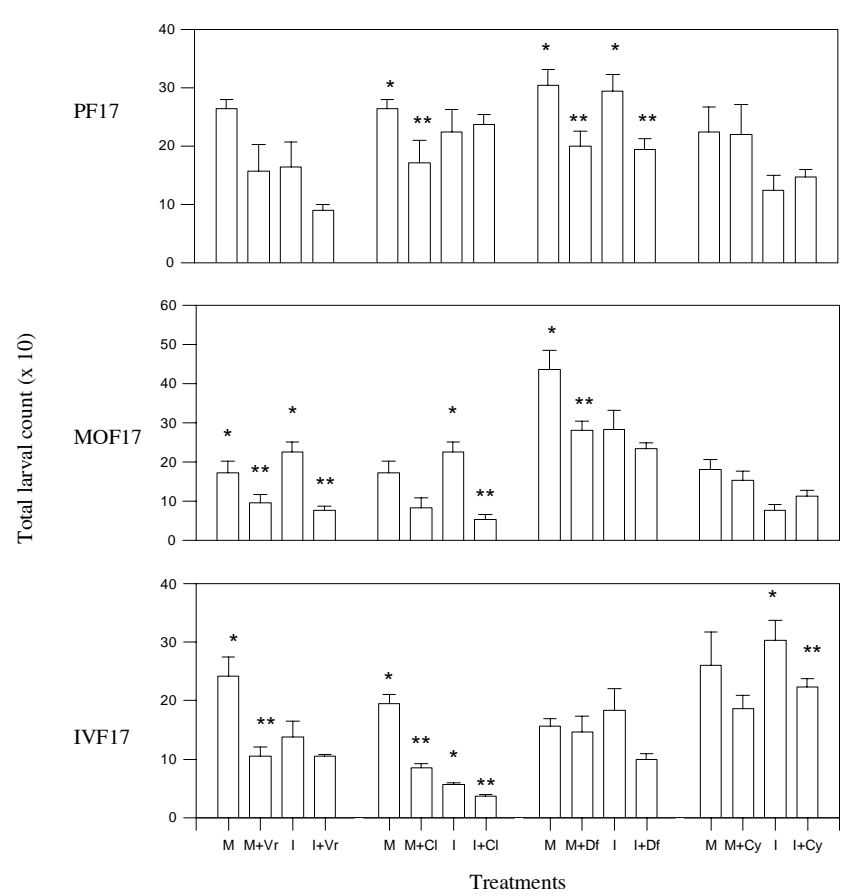

Fig. 3. Percent efficacy and comparative activity of moxidectin (M) or ivermectin (I) in the presence or absence of the multidrug resistance modulators verapamil ( $\mathrm{Vr}), \mathrm{CL} 347.099$, and cyclosporin A (Cy) against unselected and selected strains of Haemonchus contortus. *, *** Groups are significantly different $(\mathrm{P}<0.05)$.

strain, CL 347.099 (2 mM) significantly increased the efficacy of moxidectin from 59 to $82 \%(\mathrm{P}=0.028)$ and against the MOF17 from 41 to $72 \%$, leading to an increase of 38,9 and $75,6 \%$ respectively. The combination of ivermectin plus CL347.099 significantly increased the efficacy of ivermectin against the MOF17 strain from 55 to $77 \%(\mathrm{P}=0.038)$ and against the IVF17 strain from 62 to $77 \%(\mathrm{P}=0.035)$. CL 347,099 increased moxidectin's efficacy $(\mathrm{P}=0.049)$ against $\mathrm{PF} 17$ (data not shown). Cyclosporin A at $3 \mu \mathrm{M}$ had no positive effect when combined with the endectocides against PF17 or MOF17 strain, but did increase efficacy of ivermectin against the IVF1 7 strain by $37,7 \%$ (Table 1).

\section{DISCUSSION}

The in vitro migration assay is a rapid and cost effective tool for the determination of the effects of drugs that paralyze nematodes (D'Assonville et al. 1996). The facility to harvest and continuously use $\mathrm{L}_{3}$ larvae from donor animals and the ability to conduct the assessment of synergistic effects of the MDR reversing agents against the nematodes, without host modulation of drug concentrations, are additional advantages of this model. In the host, the antiparasitic drugs affect the ingested $L_{3}$ larvae once they attach to the abomasal mucosa. The strains were tested to demonstrate their resistance. Wang et al. (1995) reported that moxidectin and ivermectin had a decrease on their efficacy by 5.3 and 9.7 fold, respectively, when compared with the unselected strain after 12 generations.
The mode of action of the selected chemosensitizers as MDR reversing agents has not been fully established. Yusa \& Tsuro (1989) have showed that verapamil directly binds to Pgp, suggesting that it reverses MDR by competitively inhibiting drug transport. Verapamil and CL 347,099 have been shown to significantly increase the anthelmintic effect of ivermectin and moxidectin against selected strains of $H$. contortus in jirds (Xu et al. 1998, Molento \& Prichard 1999). However, it is possible that these P-gp antagonists may exert their effects in vivo by altering host metabolism and disposition of the anthelmintics. In the current in vitro study this possible effect was not a complication. Verapamil but not CL 347,099 is a calcium channel blocker, despite the structural similarity of these compounds. Therefore, the calcium channel blocking activity of verapamil does not appear to be involved with the increase of the endectocides activity. This is further suggested by the lack of effects of these substances by themselves against the larvae. Armson et al. (1995) have found that cyclosporin A showed no synergistic effect when administered with thiabendazole against a murine strongyloidiasis infection. On the other hand, cyclosporin A considerably enhanced the cytotoxic potency of adriamycin in several MDR gastric cancer cells lines (Holm et al. 1994). The present data have demonstrated no clear additive effect of the combination of cyclosporin A with the anthelmintics on larvae migration, at the concentration tested.

Clinical trials using the drug combination strategy in humans (verapamil and adriamycin) and verapamil alone in mice (Lonsberry et al. 1994) have demonstrated that the MDR modulators can exhibit toxic side effects. The combination of the anthelmintics and the MDR modulators has been studied in jirds (Molento \& Prichard, 1999) and in sheep (Molento et al. 1999). Verapamil has shown a dose-dependent toxic effect in both animals regardless of the presence or the absence of the anthelmintics.

These data are consistent with our previous results where the MDR modulators, verapamil and CL 347,099, augmented the antiparasitic effect of ivermectin and moxidectin against resistant strains of $H$. contortus in vivo. In the current in vitro study, in which modulation of host pharmacokinetics can be ruled out, the enhancing effects of verapamil and CL 347,099 are believed to be by means of blocking P-gp efflux activity in the nematode.

Acknowledgments.- The authors would like to thank the assistance of Mrs. C. Trudeau for the larvae preparation. This work was partially supported by Ford Dodge Animal Health. Research at the Institute of Parasitology is funded by the Natural Sciences and Engineering Research Council of Canada and the Fonds pour la Formation des Chercheurs et l'aide à la Recherche. Mr. M. B. Molento was the recipient of the Blair Postgraduate Fellowship, McGill University, Canada.

\section{REFERENCES}

Armson A., Cunninghan G.A., Grubb W.B. \& Mendis A.H. 1995. Murine strongyloidiasis: The effects of cyclosporin $A$ and thiabendazole administered singly and in combination. Int. J. Parasitol. 25:533-535.

Blackhall W., Liu H.Y., Xu M., Prichard R. \& Beech R. 1998. Selection at a Pglycoprotein gene in ivermectin and moxidectin-selected strains of Haemonchus contortus. Mol. Biochem. Parasitol. 95:193-201. 
Broeks A., Janssen H.W., Calafat J. \& Plasterk R.H. 1995. A P-glycoprotein protects Caenorhabditis elegans against natural toxins. EMBO 14:1858-1866.

Carmichael I.H., Visser R., Schneider D. \& Soll M.D. 1987. Haemonchus contortus resistance to ivermectin. J. South Afr. Vet. Assoc. 58:93.

D’Assonville J. A., Janovsky E. \& Versley A. 1996. In vitro screening of Haemonchus contortus third stage larvae for ivermectin resistance. Vet. Parasitol. 61:73-80.

Didier A. \& Loor F. 1996. The abamectin derivative ivermectin is a potent Pglycoprotein inhibitor. Anti-Cancer Drugs 7:745-751.

Greenberger L.M., Collins K.I., Annable T., Boni J.P., May M.K., Lai F.M., Kramer R., Citeralla R.V., Hallett W.A. \& Powell D. 1996. a-(3,4-dimethyoxyphenyl)3, 4-dihydro-6, 7-dimethoxy-a-[(4-methylphenyl) thiol-2(1H)-isoquinolineheptanenitrile (CL 329,753): A novel chemosensitizing agent for P-glycoprotein-mediated resistance with improved biological properties compared with verapamil and cyclosporin A. Oncol. Res. 8:207-218.

Holm P.S., Dietel M. \& Scallon K. 1994. Reversion of multidrug resistance in the P-glycoprotein-positive human pancreatic cell line (EPP85-181RDB) by introduction of a hammerhead ribozyme. Brit. J. Cancer. 70:239-243.

Leathwick D.M. 1995. A case of moxidectin failing to control ivermectin resistant Ostertagia species in goats. Vet. Rec. 136:443-444.

Lonsberry B.B., Dubo D.F., Thomas S.M., Docherty J.C., Maddaford T.G. \& Pierce G.N. 1994. Effect of high-dose verapamil administration on the $\mathrm{Ca}^{2+}$ channel density in rat cardiac tissue. Pharmacol. 49:23-3.

Lum B.L., Fisher G.A., Brophy N.A., Yahanda A.M., Adler K.M., Kaubisch S., Halsey J. \& Sikic B.I. 1993. Clinical trials of modulation of multidrug resistance. Cancer 72:3502-3514.

Molento M.B. \& Prichard R.K. 1999. Effects of the multidrug-resistancereversing agent, verapamil and CL 347,099, on the efficacy of ivermectin or moxidectin against unselected and drug-selected strains of Haemonchus contortus in jirds (Meriones unguiculatus). Parasitol. Res. 85:1007-1011.

Molento M.B., Lifschitz A., Sallovitz J., Lanusse C. \& Prichard R. 1999. Verapamil modifies the pharmacokinetics of ivermectin in sheep, p. d.1.01.
In: Proceedings of the XVII International Conference of the World Association for the Advancement of Veterinary Parasitology, Copenhagen, Denmark.

Pouliot J.F., L'Heureux F., Liu Z., Prichard R.K. \& Georges E. 1997. Reversal of P-glycoprotein-associated multidrug resistance by ivermectin. Biochem. Pharmacol. 53:17-25.

Sangster N., Bannan S., Weiss A., Nulf S., Klein R. \& Geary T. 1999. Haemonchus contortus: sequence heterogeneity of nucleotide binding domains from $\mathrm{P}$ glycoproteins and an association with avermectin/milbemycin resistance. Exp. Parasitol. 91:250-257.

Shustik C., Dalton W. \& Gros P. 1995. P-glycoprotein-mediated multidrug resistance in tumor cells. Biochemistry, clinical relevance and modulation. Mol. Aspects Med. 16:1-78.

Wadkins R.M. \& Roepe P.D. 1997. Biophysical aspects of P-glycoproteinmediated multidrug resistance. Int. Rev. Cytol. 171:121-165.

Wang G.T., Berger H., Simkins K. \& Rock D. 1995. The rate of resistance development by $H$. contortus to endectocides, p.104. In: Proceedings of the XV International Conference of the World Association for the Advancement of Veterinary Parasitology, Yokohama, Japan.

Waruiru R.M. 1997. Efficacy of closantel, albendazole and levamisole on an ivermectin resistant strain of Haemonchus contortus in sheep. Vet. Parasitol. 73:65-71.

Watanabe T., Tsuge H., Oh-Hara T., Naito M. \& Tsuruo T. 1995. Comparative study on reversal efficacy of SDZ PSC 833, cyclosporin A and verapamil on multidrug resistance in vitro and in vivo. Acta Oncol. 34:235-241.

Xu M., Molento M., Blackhall W., Ribeiro P., Beech R. \& Prichard R. 1998. Ivermectin resistance in nematodes may be caused by alteration of $\mathrm{P}$ glycoprotein homolog. Mol. Biochem. Parasitol. 91:327-335.

Yusa K. \& Tsuro T. 1989. Reversal mechanism of multidrug resistance by verapamil: Direct binding of verapamil to P-glycoprotein on specific sites and transport of verapamil outward across the plasma membrane of K562/ ADM cells. Cancer Res. 49:5002-5006. 